\title{
RADIOCARBON DATING OF SOPOT CULTURE SITES (LATE NEOLITHIC) IN EASTERN CROATIA
}

\author{
Bogomil Obelić ${ }^{1,2} \bullet$ Marija Krznarić Škrivanko ${ }^{3}$ Boško Marijan ${ }^{4}$ Ines Krajcar Bronić ${ }^{1}$
}

\begin{abstract}
The results of radiocarbon dating of several Late Neolithic archaeological sites in Slavonia, eastern Croatia, are presented. According to the archaeological findings, the sites belong to the Sopot culture. Stages I-B, II-A, II-B, and III were identified at the eponym site Sopot near Vinkovci, stages I-B and II at the site Dubovo-Košno near Županja, while findings for other investigated sites (Herrmann's Vineyard near Osijek, Mandek's Vineyard from Otok, Privlaka near Vinkovci, and Slavča near Nova Gradiška) were placed to phases II and III. ${ }^{14} \mathrm{C}$ results place the I-B stage to the period $5480-5070 \mathrm{cal} \mathrm{BC}$, stage II-A to $5030-4770 \mathrm{cal}$ BC, stage II-B to $4800-4250 \mathrm{cal} \mathrm{BC}$, and phase III to $4340-3790 \mathrm{cal}$ BC. These dates were compared to those obtained for other Late Neolithic cultures in the Pannonian Valley. The results confirmed the Protolengyel character of Sopot culture.
\end{abstract}

\section{INTRODUCTION}

Sopot culture was set apart for the first time by Milojčić (1949) as an autonomous appearance in the Late Neolithic of SE Europe and named the Slavonian-Syrmian or Babska-Lengyel culture. As a consequence of later investigations, the name Sopot-Lengyel was proposed (Dimitrijević 1968). The first part of the name was used after the eponym to designate the area of Sopot near Vinkovci, and the second part in order to stress the important role of this culture to the Lengyel culture complex in the Pannonian Valley. Subsequent excavations performed in Transdanubia showed the Protolengyel character of this culture. Therefore, only the first part of the name (Sopot) has been used since 1971, which is also in concordance with the fact that the culture is, in its essence, closer to Vinča than to Lengyel.

In this paper, we attempt to justify these assumptions by radiocarbon dating of several Sopot culture sites in eastern Croatia and by comparison with the dating of neighboring Lengyel and Vinča culture sites. Our contribution is the relative chronology of almost contemporary cultures, the genesis of the Sopot and related cultures and their chronological and cultural links.

At the Third ${ }^{14} \mathrm{C}$ and Archaeology Symposium in Lyon, Obelić et al. (1999) presented the results of ${ }^{14} \mathrm{C}$ dating of about 500 archaeological samples of charcoal, wood, grains, and human and animal bones from Slovenia, Croatia, Bosnia and Herzegovina, Serbia and Montenegro, Macedonia, and Hungary in the form of a period of existence of an archaeological site. The ${ }^{14} \mathrm{C}$ chronology of the oldest important Neolithic culture in this region, Starčevo, was systematically presented by Krajcar Bronić et al. (2003) at the Fourth ${ }^{14} \mathrm{C}$ and Archaeology Symposium in Oxford on the basis of 2 settlements. This paper, dealing with the younger Neolithic in eastern Croatia, is based mainly on excavations performed at the eponym site Sopot near the town Vinkovci (Iskra-Janošić and Krznarić Škrivanko 1997; Krznarić Śkrivanko 1998a, 1998b, 1999, 2000, 2002, 2003) and the site DubovoKošno near the town Županja (Marijan 2001). It represents a further step in the systematization of ${ }^{14} \mathrm{C}$ dating of prehistoric cultures in SE Europe performed at the Rudjer Bošković Institute in Zagreb. The results of the ${ }^{14} \mathrm{C}$ measurements were published in the Rudjer Bošković Institute data list XV (Obelić et al. 2002a).

\footnotetext{
${ }^{1}$ Rudjer Bošković Institute, P.O. Box 180, 10002 Zagreb, Croatia.

${ }^{2}$ Corresponding author. Email: Bogomil.Obelic@irb.hr.

${ }^{3}$ Vinkovci Municipal Museum, 32100 Vinkovci, Croatia.

4Županja Municipal Museum “Stjepan Gruber”, 32270 Županja, Croatia.
}

(c) 2004 by the Arizona Board of Regents on behalf of the University of Arizona

Proceedings of the 18th International Radiocarbon Conference, edited by N Beavan Athfield and R J Sparks

RADIOCARBON, Vol 46, Nr 1, 2004, p 245-258 


\section{CHARACTERISTICS OF THE SOPOT CULTURE}

The region Slavonia in eastern Croatia was one of the main arteries of cultural and ethnic trends during all prehistoric periods. There are more than 100 registered sites belonging to the Neolithic, mostly to the Sopot culture (Minichreiter 1996-97). On the area covered by the Vinkovci Municipal Museum $\left(1022 \mathrm{~km}^{2}\right), 17$ hill-forts and 6 open settlements were localized, and on the basis of casual findings, 11 more sites are supposed to exist. The favorable natural conditions enabled the high population density of the region during a continuous period of $8000 \mathrm{yr}$.

The Sopot culture is assumed to be caused by the movement of the Vinča population from presentday Serbia towards the northwest by the pressing of the ethnically superior, but culturally inferior, Starčevo culture elements into the Slavonian area. The result was the partial transformation of Starčevo ceramography, expressed in the successive introduction of biconic fine ceramic and in the decline of painted pottery. The Sopot culture is not a derivation of the Vinča culture because it is closer to Starčevo. Its ceramic production is, in essence, a very simple and static production category. Although a member of the Balkan-Anadolian cultural complex and, thus, close to the Vinča culture, it differs greatly from Vinča decorative splendor, except for a very polished surface on this simple pottery. A characteristic feature of this culture is the dark monochrome ceramic and carving and tally ornament, which was found also at the very end of the Starčevo culture under the influence of the Vinča culture. Other forms of the Sopot culture are cannelling, pressing, and ribbon decoration by incision and pricking, which is imported from the Vinča (Dimitrijević 1979). The novel feature of the Vinča is the reductive heating of ceramics (black polished), a characteristic of Balkan-Anadolian culture complex.

Archaeologists divide the Sopot culture into 3 phases (I, II, III). Dimitrijević (1968) subdivided the oldest phase into 2 stages (I-A, I-B), while newer investigations performed at the eponym site Sopot (Krznarić Škrivanko 2002) distinguish also the older (II-A) and the younger (II-B) stages of phase II. The youngest phase is denoted by III.

The central area of the Sopot culture is situated between the rivers Danube, Drava, and Sava from the Croatian-Serbian border at the east. The western border was subjected to changes during the expansion of the culture, and in its final stage, reached almost the region of today's Zagreb. By the end of the I-B stage, there was an expansion of the Sopot population towards the south, across the Sava River to northern Bosnia, as well as to the north into the Transdanubian zone in Hungary, where this Sopot manifestation was named the Sopot-Bicske culture (Dimitrijević 1979). By the beginning of phase III, an expansion towards the east, across the Danube, into the territory of the Vinča group in western Vojvodina was noticed (Brukner 1974). The main sites are presented in Figure 1.

The Sopot population was mostly agricultural. Cattle breeding, fishing, and hunting were intensive. Analyses of osteological material found at the Dubovo-Košno site confirm the existence of cow, horse, deer, boar, swine, sheep, goat, dog, and various kinds of birds. The cows and pigs are of primitive breed, i.e., changes in bones caused by domestication were not found (Jurišić, private communication). Handicraft was concentrated to pottery and production of tools and arms from stone and bones. Since a large amount of polished chisels and wedges were found at some sites, we can consider carpentry as an important activity.

The only graves of the Sopot culture in any of the investigated sites were found at Herrmann's Vineyard in Osijek, and a partial burial was found at the site Ervenica (Krznarić Škrivanko 1997), which provided minimal examples upon which to comment on the burial ritual and the spiritual life of Sopot inhabitants. It can be supposed that burial within the settlement was not usual. 


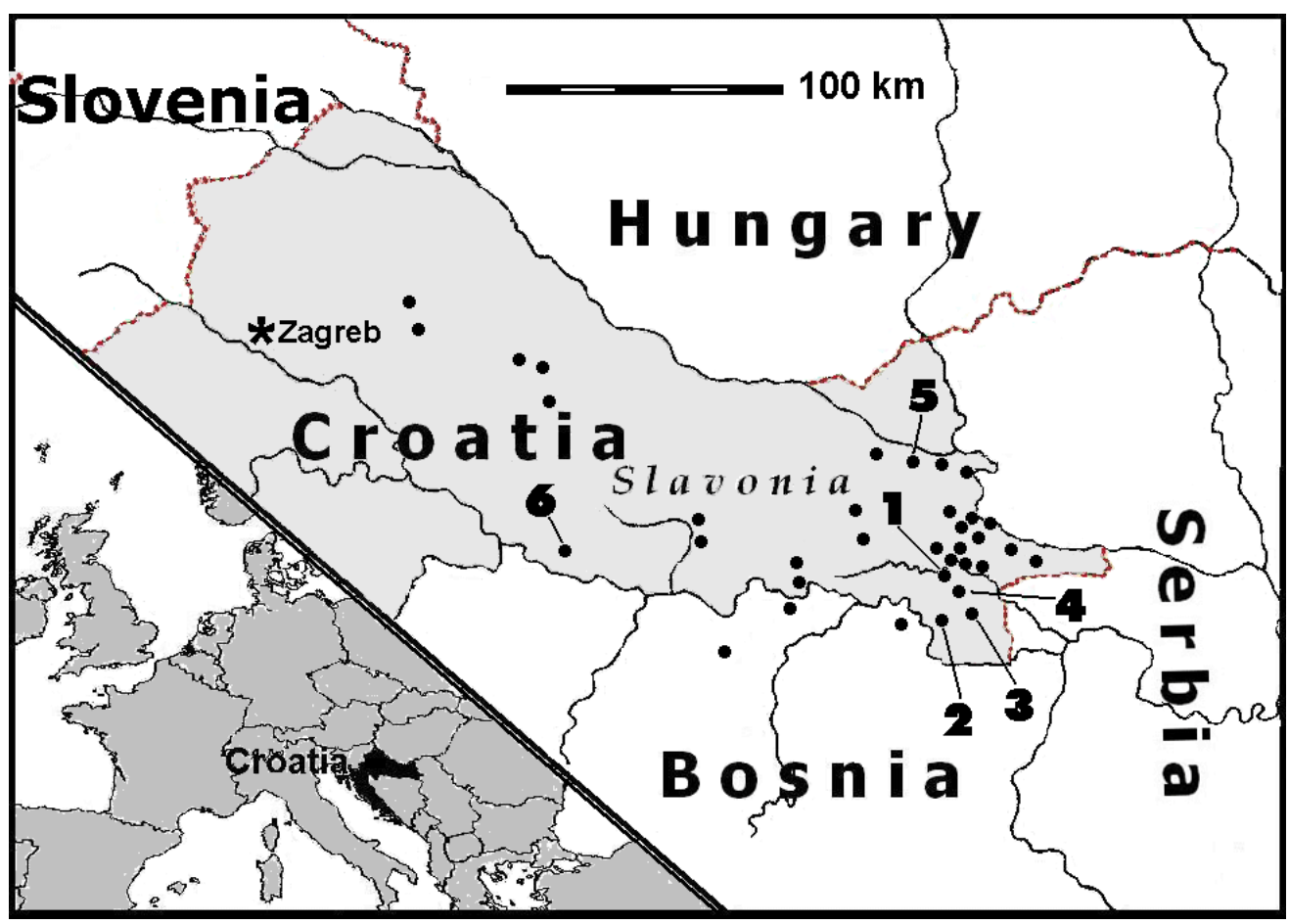

Figure 1 Main sites of Sopot culture denoted by $\bullet$. Numbers correspond to the sites from which samples were taken for ${ }^{14} \mathrm{C}$ analysis: 1-Sopot near Vinkovci, 2-Dubovo-Košno near Županja, 3-Mandek's Vineyard in Otok, 4-Privlaka, 5-Herrmann's Vineyard in Osijek, 6-Slavča near Nova Gradiška.

Investigations performed up to now indicate that the Sopot population built 2 types of houses (Krznarić Škrivanko 2002): those belonging to the II-A stage have walls constructed from horizontal beams coated with a mixture of clay and grain-husks, and those belonging to phase III were built from vertically bolted posts connected by interwoven brushwood and coated by clay and grain-husks. The strutted double roof was covered by straw.

\section{SITE DESCRIPTION}

The earliest site of the Sopot culture found in the region that covers the Vinkovci Municipal Museum was Ervenica in Vinkovci, where 7 half-buried objects were found (Krznarić Škrivanko 1997). In one of the earth-huts, a partially buried child skull was found. This ritual burial, considered as stage I-B, can be connected with the initial period of the life at the settlement. Unfortunately, no ${ }^{14} \mathrm{C}$ measurement from this site was possible.

\section{Tell Sopot}

After some investigations done in 1939 and 1940 by M Klein and 1957 by Dimitrijević (1968), systematic excavations started in 1996 at the eponym settlement Sopot near Vinkovci in eastern Slavonia (Figure 2). An elliptical tell, fortified with a palisade and a moat filled with water, is situated on the right bank of the Bosut River. Four probes of different sizes were opened, three of them within the hill-fort itself (Figure 3), and the fourth at the neighboring SW elevation. 


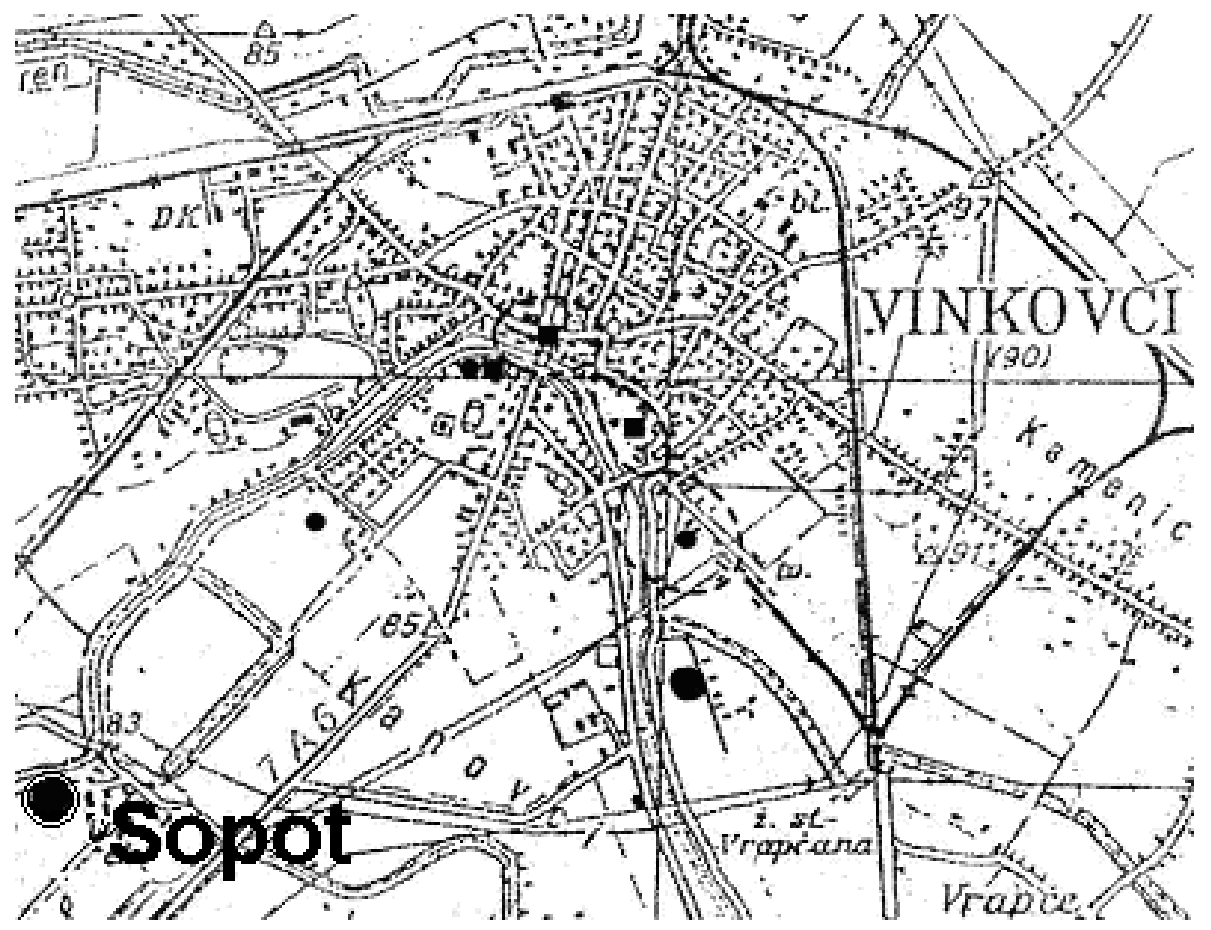

Figure 2 Sopot culture sites in Vinkovci region denoted by $\bullet$. The eponym archaeological site (southwest from the town center) is marked in bold.

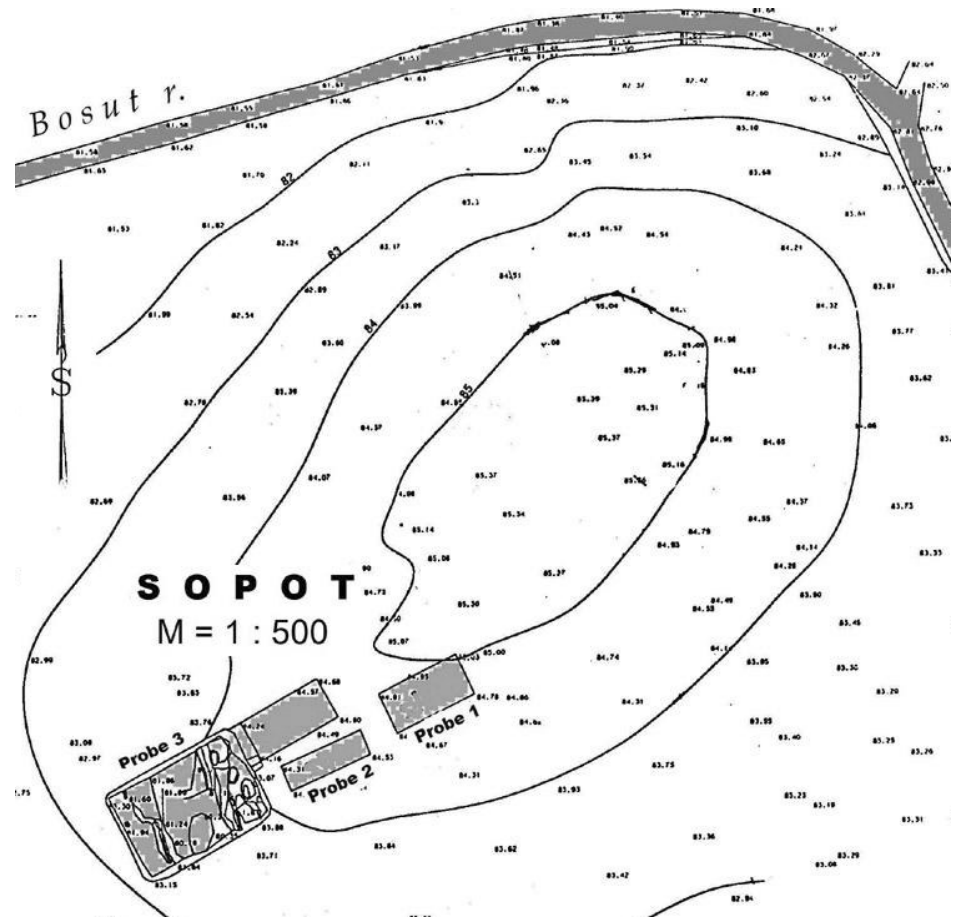

Figure 3 Geodetic plan of the Sopot site in Vinkovci with denoted probes 1, 2, and 3. 
In probe 1, several house basements from phases Sopot II to Sopot III were found. All of them were burned, except the deepest one which belongs to the oldest phase of Sopot culture. Two charcoal samples (Z-2752 and Z-2753) from this probe, taken from the basements of burned houses belonging to phase II, were submitted for ${ }^{14} \mathrm{C}$ analysis.

Further excavations were concentrated around probe 3 (Figure 3). This probe encompassed $250 \mathrm{~m}^{2}$ and was situated at the edge of the fortification close to the moat with a palisade cemented by mud. The moat was functioning during the early stage II of Sopot culture and was later filled due to the widening of the settlement.

Two house basements (SU 11 and SU 13), belonging to the latest phase III of the Sopot culture, were discovered in probe 3. The house basement, denoted as stratigraphic unit 11 (SU 11), was found on the moat. Dimensions of the house are $4 \times 6 \mathrm{~m}$ and the orientation is NW-SE. The basement was $16 \mathrm{~cm}$ deep and along it there are holes for vertical poles. An oven connected with the basement had an ash and soot infill, and numerous broken dishes were found, as well as clay weights for fishing nets or looms. The distribution of these household items seems to indicate that the inhabitants abandoned their settlement very quickly, and may be the point at which this settlement was abandoned. Three charcoal samples were taken for ${ }^{14} \mathrm{C}$ analysis (Z-2754, Z-2826, Z-2827).

Two rectangular house basements from stage II-B (SU 17 and SU 20) were discovered in probe 3 between $1-1.5 \mathrm{~m}$ depth, along a vertical line at the same position of the houses belonging to stage III (SU 11 and SU 13). They have the same orientation (NW-SE) and are made of yellow, beaten clay. Although burned, they were partially preserved in their original form. Around the houses, post holes and bigger pieces of burned clay-daub from wall construction with traces of red coloring were found. Two charcoal samples from SU 20 were dated (Z-2909, Z-2911), as well as one from SU 53 (Z-3143, nivelation of the house SU 20).

Further excavations uncovered a $7 \times 4-\mathrm{m}$ house (SU 23). Its orientation was different from that of the houses excavated at probe 3 (NE-SW). The remains of the house indicate that it was destroyed by fire. In situ finds include a large quantity of crudely fashioned household vessels and fine polished bowls and bowls with legs and numerous objects made of bone and stone. A quantity of clay weights was discovered in the SW part of the house. On the basis of a rounded pot with a low ringlike neck decorated in a typically Vinča fashion, the house was dated back to the older II-A Sopot stage. Under the house, a trench (6 m wide) was uncovered which surrounded the settlement on 3 sides (the Bosut River runs along the NW side). Below the house, there was a grayish-black layer (SU 24) with ashes and soot containing less ceramic and bone remains than the upper layers. The deepest and the oldest horizon had a lower density of houses than in the younger II-B and III stages. Charcoal samples were taken from stage II-A for ${ }^{14} \mathrm{C}$ analyses (Z-3139, Z-3140, Z-3141).

\section{Site Dubovo-Košno}

During the construction of the Zagreb-Belgrade highway section near Županja in east Slavonia, rescue excavations along the route were performed in 2000 (Figures 4 and 5). A Neolithic settlement was uncovered at the Dubovo-Košno location, where an area of $8575 \mathrm{~m}^{2}$ has been excavated. The shape of the settlement is typical for Neolithic period and belongs to the type of plain, non-fortified settlements. It consists of numerous objects, both above and below the ground. It appears that most of the sites served as workshops, while some were used as stores, wells, or waste pits, but seldom as housing objects. Conventional techniques of construction, mostly a combination of wood and muddaub, were used. 


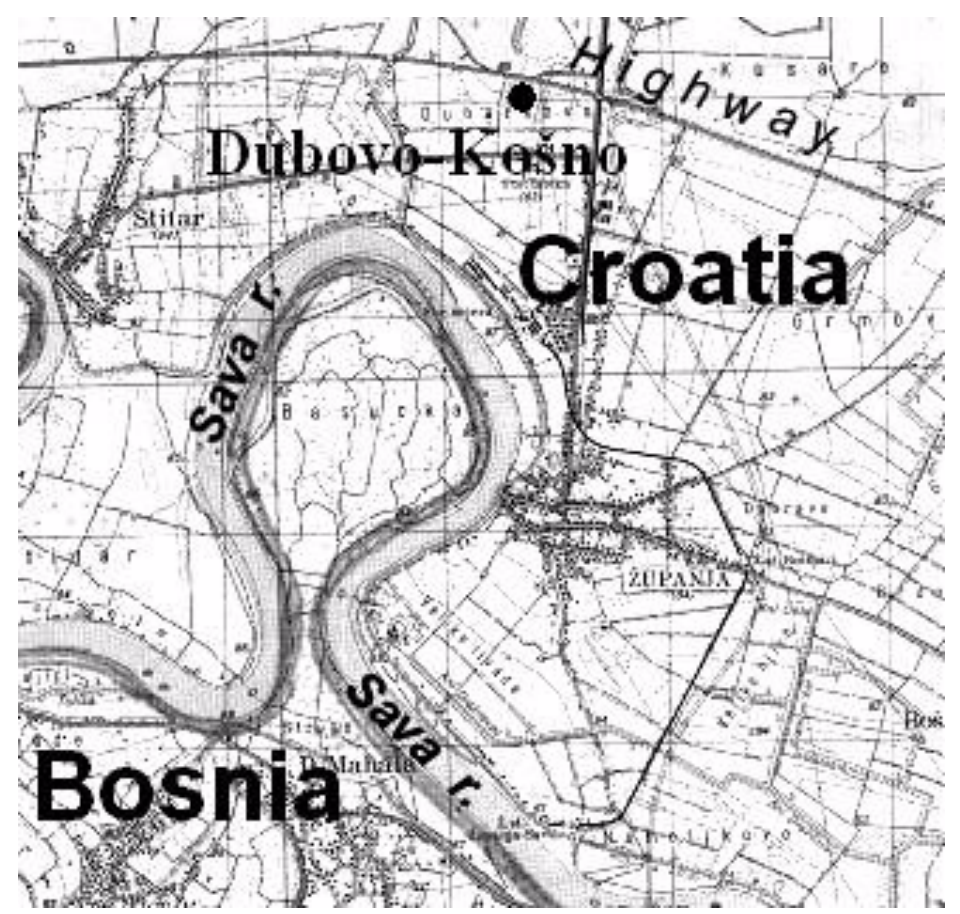

Figure 4 Position of site Dubovo-Košno

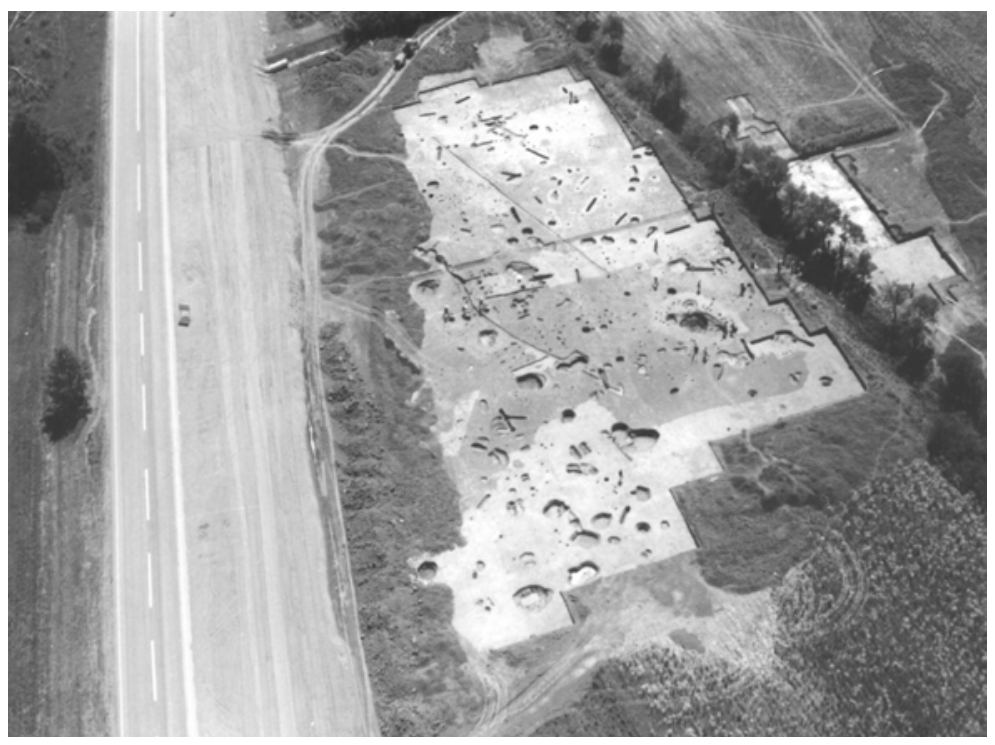

Figure 5 Dubovo-Košno site from the air. The highway route is visible.

A significant quantity of ceramic, clipped and polished stone artifacts, clay plaster, half-charred wood, animal bones, and seeds was found. A range of pottery from coarse to transitional and fine ceramic can be recognized, with pots, dishes, and beakers on solid feet. Stone and bone tools were also found, as well as a dozen weights perhaps used in trade activities. No object for exclusively cer- 
emonial or religious purposes was found. Generally, it can be concluded that it was a temporary (seasonal) settlement. Typological characteristics of the finds indicate that it was a Sopot culture settlement, a transition from stage I-B to phase II. Five samples of charred wood were taken for ${ }^{14} \mathrm{C}$ analyses (Z-2969, Z-2973, Z-2998, Z-3045, Z-3046).

\section{Other Sites}

One of the first excavations on Sopot culture sites was done by Celestin in 1897 (Celestin 1896/97) on a tell which was then Herrmann's Vineyard near Osijek. Although without stratigraphic data, the finds show at least 2 building horizons with characteristics of phases II and III of Sopot culture. Finds of interest were animal figures, numerous stone and bone artifacts, and several pendants from Spondylus. During the construction of a collector for municipal sewerage in Osijek, the excavations were continued (Šimić 1998, 1999, 2000). A sample of charcoal found near the fireplace (Z-2830) and a sample of human bone (Z-2831) were dated from this site.

The hill-fort at Mandek's Vineyard near the village of Otok, close to Vinkovci, is the ellipsoidal tellsite, bounded by a trench of $4 \mathrm{~m}$ relative height. Dimitrijević directed the excavation from 1957 and 1970 (Dimitrijević 1979). Finds belonging to all 3 phases of the Sopot culture were recovered. Samples of charcoal (Z-2762) and grain (Z-2761, Z-2913) were collected in 1970 and recently submitted for ${ }^{14} \mathrm{C}$ analysis (Obelić et al. 2002a). Grain (Triticum aestivum L.) was identified as Thell sp. vulgare by J McKey, Institute of Genetics, Uppsala, Sweden (Horvatinčić et al. 1999).

Excavations on the site Privlaka (Gradina) near Vinkovci were led by Pandžić-Majnarić in 1979. According to typological analyses, this settlement existed during phases II and III. Two samples were taken for ${ }^{14} \mathrm{C}$ analyses, Z-727 and Z-728 (Srdoč et al. 1981).

Recently, the excavation started at the Slavča site near Nova Gradiška in western Slavonia. Three samples (Z-3234, Z-3290, Z-3291) were analyzed for ${ }^{14} \mathrm{C}$. No additional information by the archaeologists is yet available and our ${ }^{14} \mathrm{C}$ dates will help in developing a chronology for the site.

\section{${ }^{14}$ C DATING}

${ }^{14} \mathrm{C}$ dating of charcoal and bones was performed in the Rudjer Bošković Institute Radiocarbon Laboratory. The samples were dated according to the standard laboratory procedures (Srdoč et al. 1971, 1979; Krajcar Bronić et al. 1995). Charcoal samples are first mechanically cleaned. The chemical treatment includes boiling in $4 \% \mathrm{HCl}$, neutralization, boiling in $2 \% \mathrm{NaOH}$, and additional boiling in a low-acid solution of $\mathrm{HCl}$ (A-B-A procedure). For bone measurements, we extracted collagen following the method introduced by Longin (1970). The dried samples are then combusted in a stream of purified oxygen. The obtained $\mathrm{CO}_{2}$ is hydrogenated to $\mathrm{CH}_{4}$ over a $\mathrm{Ru}$ catalyst at $470{ }^{\circ} \mathrm{C}$ and then purified from the residual gas impurities. Measurement of ${ }^{14} \mathrm{C}$ activity is performed in the gas proportional counter after methane was stored for about 2 weeks to allow radon to decay. Each sample is routinely measured twice and the mean value is calculated. The age is calculated following the recommendations given by Stuiver and Polach (1977) and the fractionation correction for $\delta^{13} \mathrm{C}$ is applied. The conventional ${ }^{14} \mathrm{C}$ age is calibrated using the Oxford University program OxCal (Bronk Ramsey 2001, 2003).

The quality system used in the laboratory since its beginning has been recently improved and the ISO 17025 standard has been implemented (Obelić et al. 2002b). Participation in several ${ }^{14} \mathrm{C}$ intercomparison studies (Horvatinčić et al. 1990; Krajcar Bronić et al. 1995; Radiocarbon 2001) and proficiency tests are part of the quality assurance program. 


\section{DATING RESULTS}

The results of ${ }^{14} \mathrm{C}$ dating of 25 samples from various Sopot culture sites are shown in Table 1. Both the conventional ${ }^{14} \mathrm{C}$ age and the calibrated age ranges within a 1- $\sigma$ confidence interval are given. Probabilities of the calibrated age ranges are also given and the probabilities $<5 \%$ are omitted. The graphical representation of calibrated results, sorted according to currently understood phases, is presented in Table 2.

Table 1 Overview of samples and ${ }^{14} \mathrm{C}$ results.

\begin{tabular}{|c|c|c|c|c|}
\hline $\begin{array}{l}\text { Sample } \\
\text { code }\end{array}$ & Sample description & $\begin{array}{l}\text { Conventional } \\
{ }^{14} \mathrm{C} \text { age }(\mathrm{BP})^{\mathrm{a}}\end{array}$ & $\begin{array}{l}\text { Calibrated ranges }( \pm 1 \sigma) \\
\text { and probabilities }(\%)^{\mathrm{b}}\end{array}$ & $\operatorname{Ref}^{\circ}$ \\
\hline \multicolumn{5}{|c|}{ Županja-Dubovo-Košno } \\
\hline Z-2969 & $\begin{array}{l}\text { Charcoal No.152 from pit SU 160, } \\
\text { square H-38 }\end{array}$ & $6270 \pm 140$ & cal $5320-4990$ BC $(68.2 \%)$ & {$[1]$} \\
\hline Z-2973 & $\begin{array}{l}\text { Charcoal No.214 from earth hut } \\
\text { SU148, square F-38, western part }\end{array}$ & $6530 \pm 100$ & $\begin{array}{l}\text { cal 5620-5580 BC }(8.1 \%) \\
\text { cal 5560-5460 BC }(38.4 \%) \\
\text { cal 5450-5370 BC }(21.7 \%)\end{array}$ & {$[1]$} \\
\hline Z-2998 & $\begin{array}{l}\text { Charcoal from earth hut SU } 1144 \text {, } \\
\text { square R-38/39 }\end{array}$ & $6220 \pm 100$ & cal 5300-5050 BC (68.2\%) & {$[1]$} \\
\hline Z-3045 & Charcoal, SU 1804, square Z-43d, PU 339 & $6320 \pm 100$ & $\begin{array}{l}\text { cal } 5390-5200 \text { BC }(51.2 \%) \\
\text { cal } 5170-5140 \mathrm{BC}(5.1 \%)\end{array}$ & {$[1]$} \\
\hline Z-3046 & Charcoal SU 308, square H-49d, PU 228 & $6380 \pm 100$ & cal 5480-5290 BC $(67.0 \%)$ & {$[1]$} \\
\hline \multicolumn{5}{|c|}{ Vinkovci-Sopot } \\
\hline Z-2752 & $\begin{array}{l}\text { Charcoal from basement of house, probe } 1 \text {, } \\
\text { square E-6, depth } 1.05-1.25 \mathrm{~m}\end{array}$ & $5675 \pm 120$ & $\begin{array}{l}\text { cal } 4680-4630 \text { BC }(5.8 \%) \\
\text { cal } 4620-4360 \text { BC }(62.4 \%)\end{array}$ & {$[1]$} \\
\hline Z-2753 & $\begin{array}{l}\text { Charcoal from basement of house, probe } 1 \text {, } \\
\text { square C/D-4, depth } 1.05-1.25 \mathrm{~m}\end{array}$ & $5790 \pm 125$ & cal 4780-4490 BC (68.2\%) & {$[1]$} \\
\hline Z-2754 & $\begin{array}{l}\text { Charcoal from house SU 11, probe } 3 \text {, } \\
\text { square G-9 }\end{array}$ & $5360 \pm 130$ & $\begin{array}{l}\text { cal } 4320-4270 \text { BC }(14.4 \%) \\
\text { cal } 4260-4040 \text { BC }(53.8 \%)\end{array}$ & {$[1]$} \\
\hline Z-2827 & $\begin{array}{l}\text { Charcoal from house SU 11, probe } 3 \text {, } \\
\text { square I-6, depth } 2.11 \mathrm{~m}\end{array}$ & $5380 \pm 100$ & $\begin{array}{l}\text { cal 4340-4210 BC }(36.8 \%) \\
\text { cal 4200-4140 BC }(13.5 \%) \\
\text { cal 4130-4040 BC }(17.9 \%)\end{array}$ & {$[1]$} \\
\hline Z-2909 & $\begin{array}{l}\text { Charcoal from house SU } 20 \text {, probe } 3 \text {, } \\
\text { square I-6, depth } 2.11 \mathrm{~m}\end{array}$ & $5220 \pm 100$ & $\begin{array}{l}\text { cal } 4230-4180 \text { BC }(8.9 \%) \\
\text { cal } 4170-3940 \text { BC }(59.3 \%)\end{array}$ & {$[1]$} \\
\hline Z-2911 & $\begin{array}{l}\text { Charcoal from house SU 20, probe 3, } \\
\text { square J-6, depth 3.54_3.67 m }\end{array}$ & $5330 \pm 90$ & cal $4250-4040$ BC $(66.1 \%)$ & {$[1]$} \\
\hline Z-3139 & $\begin{array}{l}\text { Charcoal from house } \overline{\mathrm{SU}} 23 \text {, probe } 3 \text {, } \\
\text { square A-8, depth } 3.89-3.99 \mathrm{~m}\end{array}$ & $6020 \pm 100$ & cal $5050-4780 \mathrm{BC}(68.2 \%)$ & {$[3]$} \\
\hline Z-3140 & $\begin{array}{l}\text { Charcoal from house SU } 23 \text {, probe } 3 \text {, } \\
\text { square C-6, depth } 3.61 \mathrm{~m}\end{array}$ & $6010 \pm 100$ & cal 5040-4770 BC (66.35\%) & {$[3]$} \\
\hline Z-3141 & $\begin{array}{l}\text { Charcoal from SU } 6 \text { of the house SU } 23 \text {, } \\
\text { probe } 3 \text {, square D-11, depth } 2.74 \mathrm{~m}\end{array}$ & $5960 \pm 100$ & cal $4960-4710$ BC $(67.2 \%)$ & {$[3]$} \\
\hline Z-3143 & $\begin{array}{l}\text { Charcoal from SU } 53 \text { (nivelation of house SU 20), } \\
\text { probe } 3 \text {, square G/H-7, depth } 3.58-3.99 \mathrm{~m}\end{array}$ & $5840 \pm 100$ & cal $4800-4580$ BC $(64.2 \%)$ & {$[3]$} \\
\hline \multicolumn{5}{|c|}{ Otok-Mandek's Vineyard } \\
\hline Z-2761 & $\begin{array}{l}\text { Grain from ceramic pot, square } 10 / \mathrm{ij} \text {, } \\
\text { depth } 0.70-0.80 \mathrm{~m}\end{array}$ & $5650 \pm 120$ & cal $4620-4350$ BC $(67.2 \%)$ & {$[1]$} \\
\hline Z-2762 & Charcoal, square 10/ij, depth $0.77 \mathrm{~m}$ & $5330 \pm 120$ & $\begin{array}{l}\text { cal } 4330-4290 \text { BC }(7.1 \%) \\
\text { cal } 4260-4040 \text { BC }(57.6 \%)\end{array}$ & {$[1]$} \\
\hline Z-2913 & Grain, same as Z-2761 & $5555 \pm 120$ & $\begin{array}{l}\text { cal } 4540-4310 \text { BC }(59.1 \%) \\
\text { cal } 4300-4250 \mathrm{BC}(9.1 \%)\end{array}$ & {$[1]$} \\
\hline \multicolumn{5}{|c|}{ Osijek-Hermann's Vineyard } \\
\hline $\mathrm{Z}-2830$ & $\begin{array}{l}\text { Charcoal from fireplace, } \\
\text { depth } 1.8-2.0 \mathrm{~m}\end{array}$ & $5260 \pm 120$ & $\begin{array}{l}\text { cal 4230-4180 BC }(7.7 \%) \\
\text { cal 4170-3930 BC }(53.2 \%) \\
\text { cal 3860-3810 BC }(7.3 \%)\end{array}$ & {$[1]$} \\
\hline Z-2831 & Human bone, depth $1.9 \mathrm{~m}$ & $5650 \pm 100$ & cal $4590-4350$ BC $(68.2 \%)$ & {$[1]$} \\
\hline \multicolumn{5}{|c|}{ Privlaka-Gradina } \\
\hline Z-727 & $\begin{array}{l}\text { Charcoal from a partially burned beam } \\
\text { in house floor, hill-fort Gradina }\end{array}$ & $6030 \pm 100$ & cal $5000-4800$ BC $(68.2 \%)$ & {$[2]$} \\
\hline Z-728 & $\begin{array}{l}\text { Wheat grains in soil } 1.7 \mathrm{~m} \text { below floor } \\
\text { of the burned house, hill-fort Gradina }\end{array}$ & $5700 \pm 80$ & cal $4620-4450$ BC $(60.1 \%)$ & {$[2]$} \\
\hline
\end{tabular}


Table 1 Overview of samples and ${ }^{14} \mathrm{C}$ results. (Continued)

\begin{tabular}{|c|c|c|c|c|}
\hline $\begin{array}{l}\text { Sample } \\
\text { code }\end{array}$ & Sample description & $\begin{array}{l}\text { Conventional } \\
{ }^{14} \mathrm{C} \text { age }(\mathrm{BP})^{\mathrm{a}}\end{array}$ & $\begin{array}{l}\text { Calibrated ranges }( \pm 1 \sigma) \\
\text { and probabilities }(\%)^{\mathrm{b}}\end{array}$ & $\operatorname{Ref}^{\mathrm{c}}$ \\
\hline \multicolumn{5}{|c|}{ Nova Gradiška-Slavča } \\
\hline Z-3234 & Charcoal from SU 37, probe 2, square B-1,2 & $5610 \pm 100$ & cal $4540-4340 \mathrm{BC}(68.2 \%)$ & [3] \\
\hline Z-3290 & Charcoal from SU 37, probe 1, square BC-3 & $5980 \pm 90$ & $\begin{array}{l}\text { cal } 4960-4770 \text { BC }(61.2 \%) \\
\text { cal } 4760-4720 \text { BC }(8.2 \%)\end{array}$ & [3] \\
\hline Z-3291 & Charcoal from SU 110, probe 1, square C-4 & $5990 \pm 90$ & cal $4990-4770 \mathrm{BC}(68.2 \%)$ & {$[3]$} \\
\hline
\end{tabular}

Table 2 Graphical presentation of ${ }^{14} \mathrm{C}$ results.

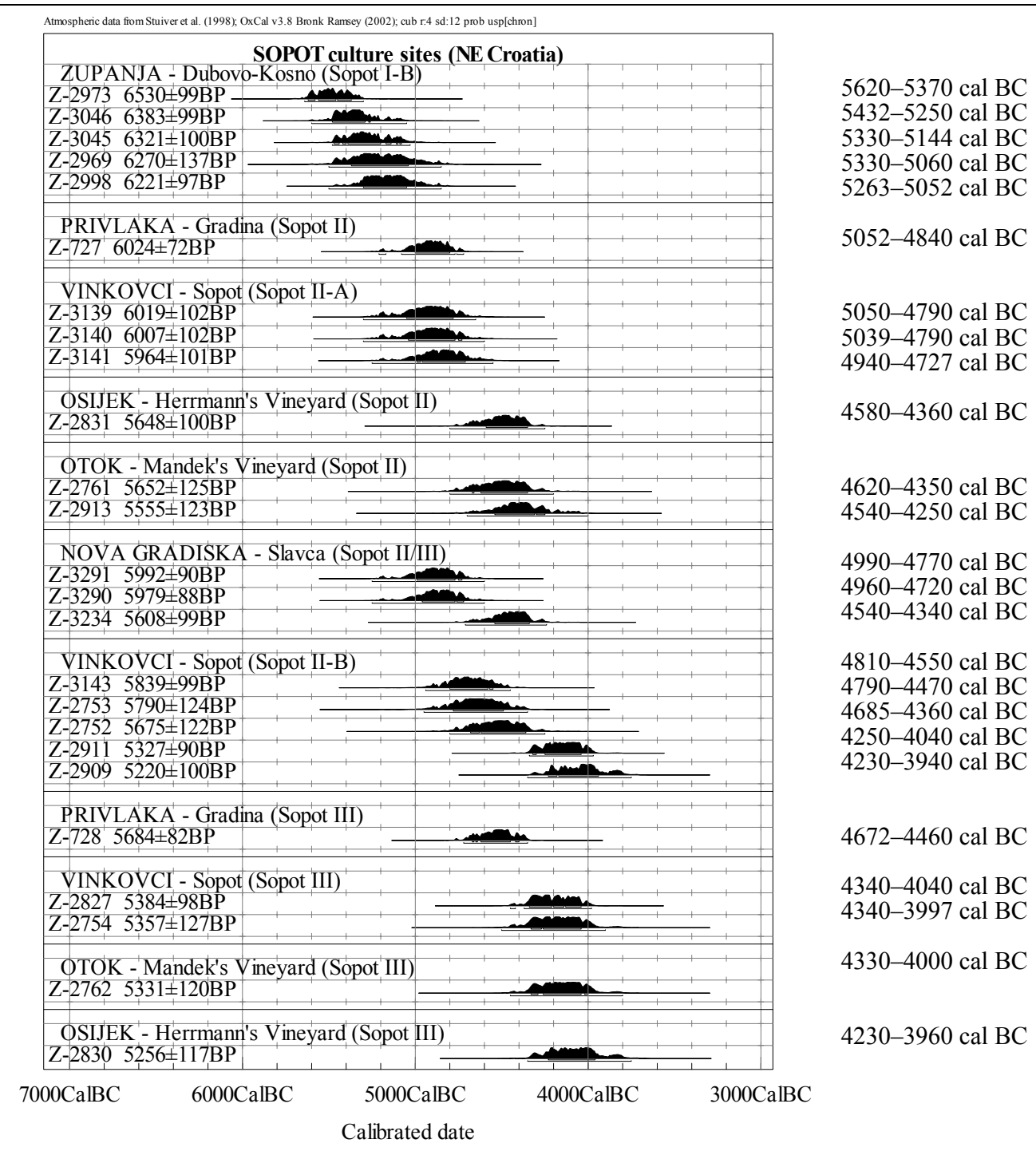


Results of all samples from the site Županja-Dubovo-Košno confirm the supposition that this site belongs to stage I-B of Sopot culture and existed for about $600 \mathrm{yr}$.

One sample from Privlaka runs into phase II and the other into phase III. Therefore, it can be supposed that the settlement existed during both phases and spanned about $600 \mathrm{yr}$.

Three samples (Z-3139, Z-3140, Z-3141) from probe 3 at tell Sopot near Vinkovci which belong to the stratigraphic unit 23 fit well into stage II-A. Samples Z-2752, Z-2753, Z-3143 agree with the supposed stage II-B, which chronologically follows and partly overlaps the previous stage II-A. However, 2 samples (Z-2909, Z-2911) from house SU 20 are younger than expected and they probably do not belong to stage II-B.

A sample of charcoal from the Herrmann's Vineyard site in Osijek found near the fireplace (Z-2830) belongs to phase III and the sample of human bone (Z-2831), found $1.9 \mathrm{~m}$ below the cultural layer, coincides with phase II of Sopot culture.

Dating of samples from Otok, the Mandek's Vineyard site, confirmed the supposition that samples of grain (Z-2761, Z-2913) belonged to phase II of Sopot culture and the charcoal sample (Z-2762) to phase III.

${ }^{14} \mathrm{C}$ results of the 2 samples from the Slavča site near Nova Gradiška show the early stages of phase II, while the third one is younger and confirms the transition from phase II to phase III.

\section{DISCUSSION}

Table 3 represents the summary of calibrated age ranges from Sopot culture sites in Slavonia, divided into phases and stages. The results of ${ }^{14} \mathrm{C}$ measurements are compared with those obtained for the Lengyel (Raetzel-Fabian 1986; Breunig 1987; Midgley 1992; Baldia 2003; Furholt et al. 2003) and Vinča cultures (Srdoč et al. 1975, 1977, 1987). The chronological distribution for a given site or phase was obtained by summation of probability distributions of individual measurements, resulting in the cumulative curve of probability of existence (Bronk Ramsey 2001, 2003). The results are summarized and compared with the ${ }^{14} \mathrm{C}$ dates of other Late Neolithic cultures from the Pannonian Valley in Figure 6.

According to Table 3 and Figure 6, stage I-B of the Sopot culture spans from 5480 to 5070 cal BC and precedes by about $160 \mathrm{yr}$ the appearance of the Vinča culture in Serbia, as well as the appearance of the Lengyel culture by about $200 \mathrm{yr}$. This fact confirms the Protolengyel character of the Sopot culture. Lenneis and Stadler (1995) in their discussion on Middle-European Linearbankeramik quote results of ${ }^{14} \mathrm{C}$ dating of 88 samples from the Vinča culture that gave the age span from 5300 to $4500 \mathrm{cal}$ BC. The same span is obtained on the basis of samples from the Vinča culture sites Selevac, Grivac, and Divostin dated in our laboratory (Srdoč et al. 1975, 1977, 1987). Sopot phase I is earlier also than the Middle Neolithic cultures of the Great Hungarian Plain: Vinča-Tordoš (5390-4960 cal BC) and Alföld linear pottery (5330-5000 cal BC) (Figure 6). Stage II-A coincides with the formation phase of the Tisza culture (5120-4710 cal BC) and II-B with the Prototiszapolgár culture in the Great Hungarian Plain (4570-4270 cal BC) (Hertelendi et al. 1995).

Unfortunately, no ${ }^{14} \mathrm{C}$ dating of the earliest (I-A) stage of the Sopot culture has been obtained. Its beginnings should coincide with the dawn of the earliest Neolithic culture which preceded Sopot, namely, the Starčevo culture (phase Linear A). Two sites of this culture in Slavonia (ZadubravljeDužine and Slavonski Brod-Galovo) are dated between 6600 and 5000 BC (Krajcar Bronić et al. 2003). Stage I-B of Sopot appeared in 5480 BC during the existence of the Starčevo culture. It means that both cultures coexisted for several hundred years in a relatively small area (approximately $50 \mathrm{~km}$ apart). 
Table 3 Comparison of age span of Sopot culture with Late Neolithic cultures in the neighborhood.

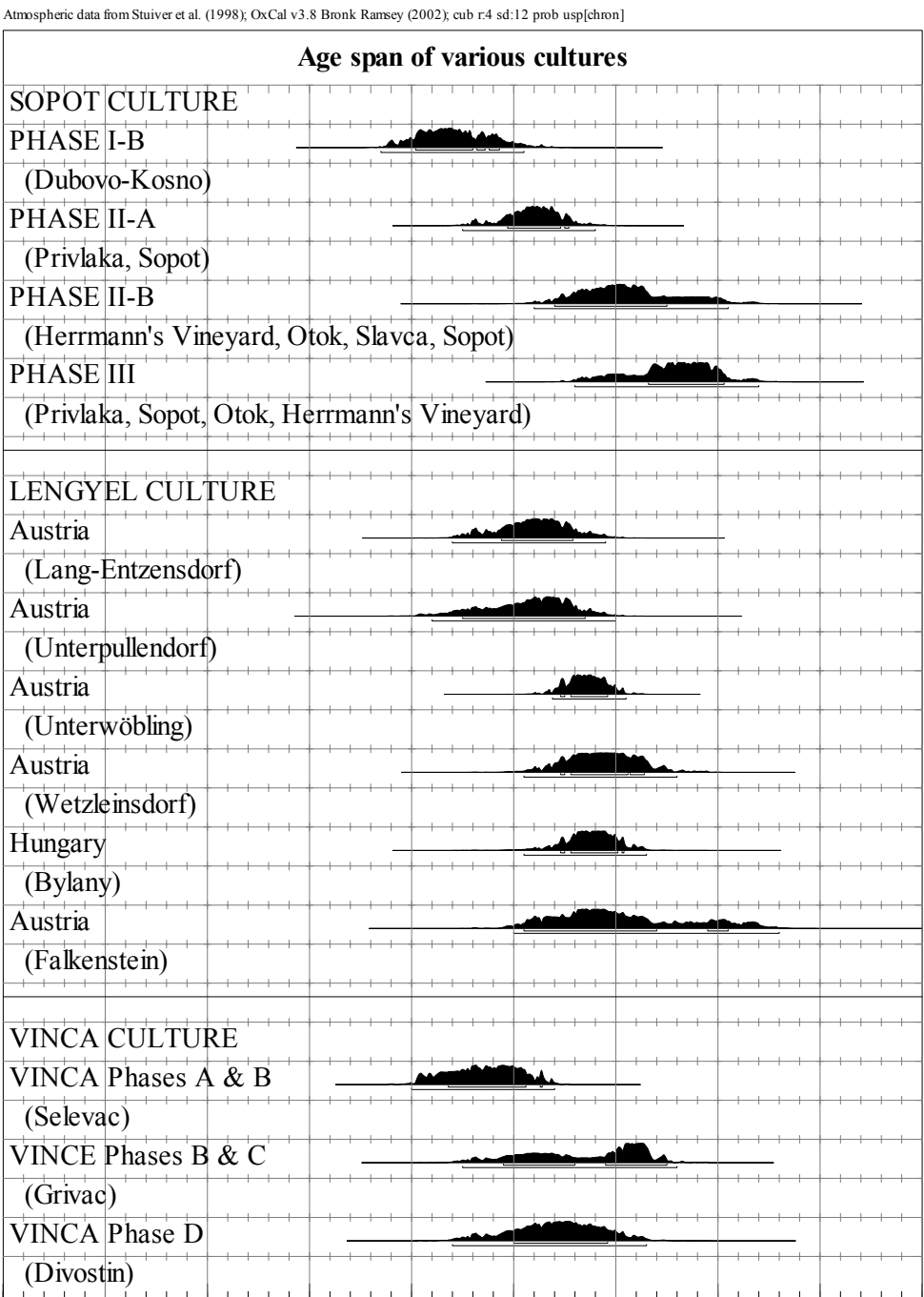

5480-5070 cal BC

5030-4770 cal BC

$4800-4250$ cal BC

4340-3790 cal BC

5060-4720 cal BC

$5250-4650$ cal BC

$4720-4540$ cal BC

$4720-4360$ cal BC

$4720-4490$ cal BC

$4950-4300$ cal BC

5320-4940 cal BC

$5050-4250$ cal BC

5000-4540 cal BC

$7500 \mathrm{BC} 7000 \mathrm{BC} 6500 \mathrm{BC} 6000 \mathrm{BC} 5500 \mathrm{BC} 5000 \mathrm{BC} 4500 \mathrm{BC} 4000 \mathrm{BC} 3500 \mathrm{BC} 3000 \mathrm{BC}$

Calendar date

In our introduction, we stated that Sopot culture is supposed to appear as the result of the movement of the Vinča culture towards the north. Here we present dates of stage I-B of the Sopot culture (5480-5070 cal BC) that are older than about 100 samples (Lenneis and Stadler 1995; Srdoč et al. $1975,1977,1987)$ of the Vinča culture $(5300-4500$ cal BC). This chronology would, thus, not justify the assumption. Therefore, a question remains: If the Sopot culture is the consequence of forcing the Starčevo culture elements towards the west by the second wave of the Vinča population (Dimitrijević 1979: 262), why are there no dates of the Vinča which precede the earliest Sopot ${ }^{14} \mathrm{C}$ results?

The Sopot culture was succeeded by the Copper (Eneolithic) Lasinja culture, which in its essence represents still a proper offspring of the Late Neolithic. No one copper object was found at the Las- 


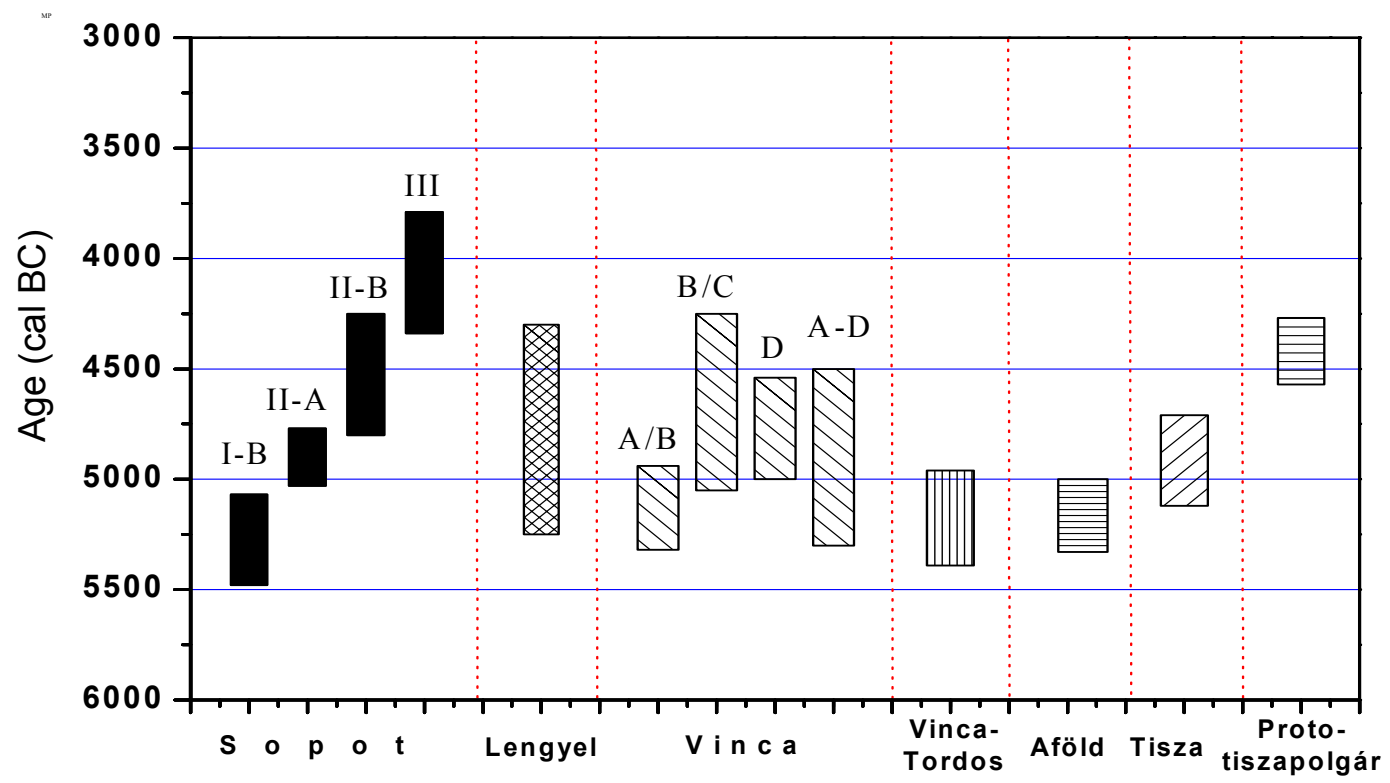

Figure 6 Comparative ${ }^{14} \mathrm{C}$ chronology of Late Neolithic cultures in Pannonian valley. Sopot: present results; Lengyel: Baldia 2003; Furhold et al. 1995; Vinča A/B, B/C and D: Srdoč et al. 1975, 1977, 1987; Vinča A-D:Lenneis and Stadler 1995; Vinča-Tordos, Aföld, Tisza, Prototiszapolgár: Hertelendi et al. 1995

inja sites in Croatia until now. The earliest dates for the Lasinja culture are from the site Koprivnički bregi in NW Croatia, giving 3500 BC (Obelić et al. 1999). The proper representatives of the Early Eneolithic are the bearers of the Baden culture (Težak-Gregl 1998). The beginning of Baden culture in eastern Croatia was dated to 3800 BC (Obelić et al. 1999).

Further ${ }^{14} \mathrm{C}$ dates from early Sopot culture sites are certainly required to further define the role of the Vinča culture in the development of the Sopot. From our own excavations and analysis, a possible revision of established archaeological assumptions for the region is foreseen in light of new dates and archaeological investigation of Sopot culture sites.

\section{REFERENCES}

Baldia M. 2003. The Comparative Archaeology WEB. URL: http://www.comp-archaeology.org. Accessed 15 January 2004.

Breunig P. 1987. ${ }^{14} \mathrm{C}$ Chronologie des vorderasiatischen, südost- und mitteleuropäischen Neolithikums $\left[{ }^{14} \mathrm{C}\right.$ chronology of the Preasiatic, South-East and MiddleEuropean Neolithic]. Fundamenta (Köln): Reihe A, Band 13.

Bronk Ramsey C. 2001. Development of the radiocarbon program OxCal. Radiocarbon 43(2A):355-63.

Bronk Ramsey C. 2003. OxCal Program v.3.9-The Manual. University of Oxford, Radiocarbon Accelerator Unit. URL: http://www.rlaha.ox.ac.uk/ oxcal/oxcal.htm. Accessed 15 January 2004.

Brukner B. 1974. Sopotsko-Lenđelska grupa [The SopotLengyel group]. In: Praistorija Vojvodine, Novi Sad: 95-103.

Celestin V. 1896/97. Neolitska naseobina kod Osijeka [A
Neolithic Settlement near Osijek]. Vjesnik Hrvatskog arheološkog društva, Zagreb.

Dimitrijević S. 1968. Sopotsko-Lenđelska kultura [The Sopot-Lengyel culture]. Monographiae Archaeologicae (Zagreb) I:1-123.

Dimitrijević S. 1979. Sjeverna zona [Northern zone]. In: Benac A, editor. Praistorija jugoslavenskih zemalja: Neolit. Sarajevo: Academy of Sciences and Arts of Bosnia and Herzegovina. p 229-362.

Furholt M, Müller J, Raetzel-Fabian D, Rinne C, Wotzka HP. 2003. RADON: Radiocarbon dates online (in German). URL: <http://www.jungsteinsite.de/radon/radon.htm>. Accessed 15 January 2004.

Hertelendi E, Kalicz N, Raczky P, Horváth F, Veres M, Svingor E, Futó I, Bartosiewicz L. 1995. Re-evaluation of the Neolithic in Eastern Hungary based on calibrated radiocarbon dates. Radiocarbon 37(2):23944. 
Horvatinčić N, Obelić B, Krajcar Bronić I, Srdoč D, Čalić R. 1999. Rudjer Bošković Institute radiocarbon measurements XIV. Radiocarbon 41(2):199-214.

Horvatinčić N, Srdoč D, Obelić B, Krajcar Bronić I. 1990. Radiocarbon dating of intercomparison samples at the Zagreb Radiocarbon Laboratory. Radiocarbon 32(3):295-300.

Iskra-Janošić I, Krznarić Škrivanko M. 1997. Sustavno istraživanje neolitičkog naselja Sopot pokraj Vinkovaca [Systematic explorations of Sopot Neolithic settlement near Vinkovci]. Obavijesti Hrvatskog arheološkog društva (Zagreb) year XXIX, nr 1:20-4.

Krajcar Bronić I, Horvatinčić N, Obelić B, Bistrović R. 1995. Radiocarbon intercomparison studies at the Rudjer Bošković Institute. Radiocarbon 37(2):80511.

Krajcar Bronić I, Minichreiter K, Obelić B, Horvatinčić N. Forthcoming. The oldest early Neolithic (Starčevo culture) settlements in Croatia: Zadubravlje-Dužine and Slavonski Brod-Galovo. 4th International Symposium " ${ }^{14} \mathrm{C}$ and Archaeology", Oxford, England, UK, 9-14 April 2002.

Krznarić Škrivanko M. 1997. Prapovijesno naselje na Ervenici u Vinkovcima [The prehistoric settlement of Ervenica in Vinkovci]. Opuscula Archaeologica (Zagreb) 21:205-15.

Krznarić Škrivanko M. 1998a. Druga etapa sustavnog arheološkog iskopavanja gradine Sopot [Second stage of systematic archaeological excavations on gradina Sopot]. Obavijesti Hrvatskog arheološkog društva (Zagreb) year XXX, $n r$ 1:30-4.

Krznarić Škrivanko M. 1998b. Treća sezona iskopavanja na gradini Sopot [Third stage of excavations on gradina Sopot]. Obavijesti Hrvatskog arheološkog društva (Zagreb) year XXX, nr 3:71-4.

Krznarić Škrivanko M. 1999. Mlađe kameno doba [Neolithic in Vinkovci]. In: Catalogue Vinkovci u svijetu arheologije. p 11-21.

Krznarić Škrivanko M. 2000. Četvrta sezona sustavnog istraživanja gradine Sopot [Fourth season of systematic investigations of gradina Sopot]. Obavijesti $\mathrm{Hr}$ vatskog arheološkog društva (Zagreb) year XXXII, nr 2:49-52.

Krznarić Škrivanko M. 2002. Peta i šesta sezona sustavnog istraživanja gradine Sopot [Fifth and sixth season of systematic investigations of gradina Sopot]. Obavijesti Hrvatskog arheološkog društva (Zagreb) year XXXIV, nr 2:36-45.

Krznarić Škrivanko M. 2003. Sedma sezona sustavnog istraživanja gradine Sopot (godina 2002.) [Systematic Excavations at the Sopot hill-fort, seventh campaign -2002]. Obavijesti Hrvatskog arheološkog društva (Zagreb) year XXXV, nr 1:37-46.

Lenneis E, Stadler P. 1995. Zur Absolutchronologie der Linearbandkeramik aufgrund von ${ }^{14} \mathrm{C}$-daten [Absolute chronology of Linear-band Ceramic according to ${ }^{14} \mathrm{C}$ dates]. Archäologie Österreichs 6/2:4-13.
Longin R. 1970. New method of collagen extraction for radiocarbon dating. Nature 230:231-42.

Marijan B. 2001. Zaštitna istraživanja arheoloških lokaliteta uz južni trak autoceste Zagreb-Lipovac, dionica Velika Kopanica-Županja, poddionica Babina Greda-Županja [Archaeological rescue excavations at the site along the southern carriageway of the motorway Zagreb-Lipovac, section Velika KopanicaŽupanja, subsection Babina Greda-Županja]. Obavijesti Hrvatskog arheološkog društva (Zagreb) year XXXIII, $n r$ 2:35-45.

Midgley MS. 1992. TRB Culture: The First Farmers of the North European Plain. Edinburgh: Edinburgh University Press. 550 p.

Milojčić V. 1949. Chronologie der Jüngeren Steinzeit Mittel- und Südosteuropas [Chronology of the Neolithic in Middle and Southern Europe]. Berlin: Deutsches Archaeologisches Institut. 136 p.

Minichreiter K. 1996-1997. Zoomorfna idoloplastika obredno-ukopnog prostora starčevačkog lokaliteta na Galovu u Slavonskom Brodu [Zoomorphic idols of the Starčevo ceremonial and burial area site at Galovo, Slavonski Brod]. Prilozi Instituta za arheologiju u Zagrebu 13-14:7-22.

Obelić B, Horvatinčić N, Durman A. 1999. Radiocarbon chronology of archaeological sites in southeastern Europe. Mémoires de la Société Préhistorique Française (Supplement 1999 de la Revue d'Archéoméetrie) Tome 26:233-8.

Obelić B, Horvatinčić N, Krajcar Bronić I. 2002a. Rudjer Bošković Institute radiocarbon measurements XV. Radiocarbon 44(3):601-30.

Obelić B, Horvatinčić N, Krajcar Bronić I. 2002b. Improving of quality control and quality assurance in Radiocarbon and Tritium Laboratory; participation in the IAEA model project. Regional IRPA Congress on Radiation Protection in Central Europe-"Radiation Protection and Health", Dubrovnik, 20.05.200125.05.2001., Proceedings: 10-09.

Radiocarbon. 2001. Report on the FIRI Workshop, Edinburgh March 2001. University of Arizona, Tucson. URL: $<$ http://www.radiocarbon.org_Announcements/ FIRI-results.html $>$. Accessed 2004 January 15.

Raetzel-Fabian D. 1986. Phasenkartierung des mitteleuropäischen Neolithikums [Phase mapping of MiddleEuropean Neolithic]. Chronologie und Chorologie. B.A.R. International Series: 316.

Šimić J. 1998. Istraživanje neolitičkog nalazišta OsijekFilipovica/Hermanov vinograd [Investigations of the Neolithic site Osijek-Filipovica/Herrmann's Vineyard]. Glasnik slavonskih muzeja (Županja) 2(57): 69-72.

Šimić J. 1999. Osijek-Filipovica (Hermanov vinograd), zaštitno iskopavanje neolitičkog naselja [Osijek-Filipovica (Herrmann's Vineyard), rescue excavations of a Neolithic settlement]. Obavijesti Hrvatskog arheološkog društva (Zagreb) year XXXI, nr 1:30-3. 
Šimić J. 2000. Istraživanje neolitičkog lokaliteta Hermanov vinograd u Osijeku [Investigations of the Neolithic site Herrmann's Vineyard in Osijek]. Histria antiqua (Pula) 6:223-30.

Srdoč D, Breyer B, Sliepčević A. 1971. Rudjer Bošković Institute radiocarbon measurements I. Radiocarbon 13(1):135-40.

Srdoč D, Obelić B, Horvatinčić N, Sliepčević A. 1979. Measurement of the ${ }^{14} \mathrm{C}$ activity of the ANU sucrose secondary standard by means of the proportional counter technique. Radiocarbon 21(3):321-8.

Srdoč D, Obelić B, Sliepčević A, Krajcar Bronić I, Horvatinčić N. 1987. Rudjer Bošković Institute radiocarbon measurements X. Radiocarbon 29(1):135-47.

Srdoč D, Sliepčević A, Obelić B, Horvatinčić N. 1977.

Rudjer Bošković Institute radiocarbon measurements IV. Radiocarbon 19(3):465-75.
Srdoč D, Sliepčević A, Obelić B, Horvatinčić N. 1981. Rudjer Bošković Institute radiocarbon measurements VI. Radiocarbon 23(3):410-21.

Srdoč D, Sliepčević A, Planinić J. 1975. Rudjer Bošković Institute radiocarbon measurement III. Radiocarbon 17(1):149-55.

Stuiver M, Polach HA. 1977. Discussion: reporting of ${ }^{14} \mathrm{C}$ data. Radiocarbon 19(3):355-63.

Stuiver M, Reimer PJ, Bard E, Beck JW, Burr GS, Hughen KA, Kromer B, McCormac G, van der Plicht J, Spurk M. 1998. INTCAL98 radiocarbon age calibration, 24,000-0 cal BP. Radiocarbon 40(3):104183.

Težak-Gregl T. 1998. Neolitik i eneolitik [Neolithic and Eneolithic]. In: Dimitrijević S, Težak-Gregl T, Majnarić-Pandžić N, editors. Prapovijest. Zagreb: Naprijed. p 59-151. 